\title{
Surgical casuistic in dogs at a Veterinary Hospital - Piauí State Federal University
}

\section{Casuística cirúrgica em cães de um Hospital Veterinário - Universidade Federal do Piauí}

\author{
Nhirneyla Marques Rodrigues ${ }^{1}$; Ana Maria Quessada²; Ana Paula Barros Fonseca*3 (1); \\ Sávio Soares Barbosa Dantas ${ }^{1}$; Jaqueline Lustosa Rodrigues Camapum ${ }^{1}$; Filipi Alexandre do Nascimento Silva ${ }^{3}$ \\ ${ }^{1}$ Universidade Federal do Piauí (UFPI), Teresina - PI, Brazil \\ ${ }^{2}$ Universidade Paranaense, Programa de Pós-graduação em Ciência Animal, Umuarama - PR, Brazil \\ ${ }^{3}$ Universidade Federal do Piauí, Centro de Ciências Agrárias, Programa de Pós-graduação em Ciência Animal, Teresina - PI, Brazil
}

\begin{abstract}
The objective of this report was to record surgical procedures performed in 241 dogs in a teaching veterinary hospital. There were 40 elective surgical procedures (16.6\%) and 201 therapeutic surgical procedures (83.4\%). The most frequent procedure was ovariohysterectomy $(\mathrm{OH}), 65 \%(26 / 40)$ and $24.38 \%(49 / 201)$, respectively, for elective and therapeutic surgical procedures. Among therapeutic surgical procedures were registered fracture reduction $(16.91 \%, 34 / 201)$, mastectomies $(13.93 \%, 28 / 201)$, drainage of the otohematoma $(12.94 \% ; 26 / 201)$ and ophthalmic surgical procedures $(5.47 \%, 11 / 201)$. The high percentage of therapeutic surgical procedures conducted demonstrates the complexity of the cases attended daily in a teaching veterinary hospital.
\end{abstract}

Keywords: Canines. Surgery. Survey. Ovariohysterectomy.

\section{RESUMO}

O presente relato tem o objetivo de registrar procedimentos cirúrgicos realizados em 241 cães em um Hospital Veterinário Universitário. Foram realizados 40 procedimentos cirúrgicos eletivos $(16,6 \%)$ e 201 procedimentos cirúrgicos terapêuticos $(83,4 \%)$. Em ambos os casos, o procedimento mais frequente foi ovariosalpingohisterectomia (OSH), 65\% (26/40) e 24,38\% (49/201) respectivamente para procedimentos cirúrgicos eletivos e terapêuticos. Entre os procedimentos cirúrgicos terapêuticos foram registradas redução de fraturas $(16,91 \% ; 34 / 201)$, mastectomias $(13,93 \%$; $28 / 201)$, drenagem de otohematomas $(12,94 \% ; 26 / 201)$ e procedimentos cirúrgicos oftálmicos $(5,47 \% ; 11 / 201)$. A alta porcentagem de procedimentos cirúrgicos terapêuticos demonstra a complexidade dos casos atendidos diariamente em um Hospital Escola.

Palavras-chave: Canino. Cirurgia. Levantamento. Ovariosalpingohisterectomia.

Correspondence to:

Ana Paula Barros Fonseca

Universidade Federal do Piauí, Campus Universitário Ministro

Petrônio Portela

Rua Dirce de Oliveira, 3597, Bairro Ininga

CEP: 64049-550, Teresina - PI, Brazil

e-mail: anapaula-92@hotmail.com

Submited: June 2, 2018

Approved: February 4, 2019
How to cite: Rodrigues NM, Quessada AM, Fonseca APB, Dantas SSB, Camapum JLR, Silva FAN. Surgical casuistic in dogs at a Veterinary Hospital - Piauí State Federal University. Braz J Vet Res Anim Sci. 2019;56(1):e146660. https://doi.org/10.11606/issn.16784456.bjvras.2019.146660.

It is known that improvement in the quality of life of companion animals generally improves their longevity (Bentubo et al., 2003). Such increased longevity may be associated with increased diagnosis of diseases (Ribeiro, 2016), 
and some diseases can be surgically corrected. However, studies quantifying the types of surgical procedures adopted for treating dogs in Brazil and the rationale behind adopting these procedures are still scarce (Cruz-Pinto et al., 2015). To contribute new data on this understudied subject, in this study, we recorded the surgical procedures performed on canines (i.e. domestic dogs) at a university veterinary hospital (UVH) located in Teresina (Piauí, Brazil) over a 7-month period.

All dogs undergoing surgical procedures during the study period (November 2011 to June 2012) were included in our assessment. Information on surgical interventions was obtained, and the results were converted into percentages of all patients (total $=241 \mathrm{dogs}$ ) for presentation and discussion.

The majority of patients were females $(158 / 241,65.56 \%)$, and a minority of patients were male (83/241, 34.44\%). Probably, this majority of female patients may be related to the great demand for elective spaying of bitches (Inoe et al., 2004; Silveira et al., 2013)

Breed was not defined for most of the dogs treated. This result reflects the UVH clientele, for whom most of the canines brought in as patients are mongrel dogs, as was also observed in another locality (Franco \& Silva-Molano, 2009).

There were $40(16.60 \%)$ elective surgical procedures performed, which consisted of 26 (26/40, 65\%) ovariohysterectomies $(\mathrm{OH}), 13$ orchiectomies $(32.5 \%)$, and one amputation of the first digit (2.5\%) (Table 1). All patients were healthy, according to pre-surgery evaluations. For elective surgical procedures, animals that are not ready should be treated and monitored until the appropriate time (Shmon, 2007).

Sterilization was more frequently performed on females than males. This procedure is very prevalent because many owners want to avoid unwanted offspring and future reproductive diseases, mainly mammary tumor (Magalhães et al., 2016) and pyometra (Evangelista et al., 2010).

There was $100 \%$ success in these elective surgical procedures, with no death. Such a result is generally expected in these cases (Shmon, 2007).

Of the total 241 surgical procedures performed, 201 were considered therapeutic (83.4\%). Such results are expected in a university teaching hospital like the one in this study, where most cases are complex and forwarded by other veterinary hospitals. Among the 201 surgical procedures considered therapeutic, the most common were $\mathrm{OH}$ (49/201, 24.38\%). The most frequent illness that led to $\mathrm{OH}$ surgical procedures was pyometra, in 32 of 49 cases $(65.30 \%)$. These results are similar to those reported in other studies in Brazil (Silveira et al., 2013; Cruz-Pinto et al., 2015). The remaining 17 therapeutic $\mathrm{OH}$ surgical procedures were performed because of dystocic parturition and fetal death (34.69\%).

Fracture reduction surgeries were the second most frequent, constituting 34 of 201 therapeutic surgical procedures (16.9\%), which is reasonable given that fractures are commonly dealt with in veterinary clinical practices on the canine species (Kemper \& Diamante, 2010; Souza et al., 2011).

Mastectomies were performed in 28 of 201 cases $(13.93 \%)$, representing the third most frequent type of

Table 1 - Surgical procedures performed on dogs at a university veterinary hospital (Teresina, Piauí, Brazil) over November 2011 to June $2012(\mathrm{n}=241)$

\begin{tabular}{|c|c|c|c|c|}
\hline & \multicolumn{2}{|c|}{ Elective surgical procedures } & \multicolumn{2}{|c|}{ Therapeutic surgical procedures } \\
\hline & Number & Percentages & Number & Percentages \\
\hline Ovariohysterectomy & 26 & $10,79 \%$ & 49 & $20,33 \%$ \\
\hline Fracture reduction & & & 34 & $14,11 \%$ \\
\hline Mastectomies & & & 28 & $11,62 \%$ \\
\hline Drainage of the otohematoma & & & 26 & $10,79 \%$ \\
\hline Ophthalmic surgical procedures & & & 11 & $4,56 \%$ \\
\hline Orchiectomies & 13 & $5,40 \%$ & 07 & $2,90 \%$ \\
\hline Cutaneous sutures & & & 06 & $2,49 \%$ \\
\hline Cystotomies & & & 05 & $2,07 \%$ \\
\hline Ablation of the scrotal sac & & & 05 & $2,07 \%$ \\
\hline Perineal herniorrhaphy & & & 05 & $2,07 \%$ \\
\hline Corrections of luxations & & & 05 & $2,07 \%$ \\
\hline Removal of neoplasias & & & 05 & $2,07 \%$ \\
\hline Amputation of the digit & 01 & $0,41 \%$ & & \\
\hline Others & & & 15 & $6,22 \%$ \\
\hline Total & 40 & $16,6 \%$ & 201 & $83,4 \%$ \\
\hline
\end{tabular}


surgical procedure performed for a disease. Mammary tumors (MT) are the most frequent type of neoplasia among dogs in Brazil (Biondi et al., 2014).

Drainage of otohematoma was performed on 26 patients $(26 / 201,12.94 \%)$. This surgical procedure is frequently performed by veterinary services in Brazil (Cruz-Pinto et al., 2015; Rodrigues et al., 2016; Xavier, 2012).

Among the 201 therapeutic surgical procedures, 11 were considered ophthalmic (5.47\%). Of these, four entropy corrections were performed $(4 / 11,36.36 \%)$, three enucleations of the eyeball (27.27\%), two replacements of the third eyelid gland (18.18\%), and two repairs of the flaps of the third eyelid (for correction of corneal ulcer) (18.18\%). Ophthalmic surgical procedures are common in veterinary clinical practices (Niza, 2015; Xavier, 2012)

Seven orchiectomies were carried out for therapeutic reasons $(7 / 201,3.48 \%)$, most often for treatment of prostatic hypertrophy. Orchiectomy is the most effective treatment for dogs affected by this condition (Mostachio et al., 2015).

Further, six cases of cutaneous sutures $(6 / 201,2.99 \%)$ were recorded, mostly due to trauma. In other veterinary services, it is also common to suture cutaneous wounds (Niza, 2015; Xavier, 2012). It is inferred that this result was observed because traumas are frequent among the canine species (Fighera et al., 2008; Lopes, 2016; Vidane et al., 2014).

Five luxation's were corrected surgically (5/201, $2.49 \%$ ), three of the patella and two of the coxofemoral joint. Patellar dislocation is one of the most common abnormalities affecting the knees of dogs (Bezerra et al., 2013; Souza et al., 2009). Traumatic hip dislocations are important orthopedic conditions in dogs, with a high incidence due to trauma (Barbosa \& Schossler, 2009), as detected in the present study.

Five cystotomies $(2.49 \%)$ were performed, all with a diagnosis of urolithiasis. Such a condition is relatively common in small animal medicine, and the treatment of choice is surgical intervention (Silva et al., 2013).

Ablation of the scrotal sac was performed in five dogs $(5 / 201 ; 2.49 \%)$ to treat for diseases, mainly severe scrotal dermatitis.

Perineal herniorrhaphy was performed in five patients $(5 / 201,2.49 \%)$. Surgical treatment, adopted in the present study, is the most effective method to repair hernias (Marques et al., 2015; Mortari \& Rahal, 2005; Ribeiro, 2010). However, there is a successful employment report of the association of the techniques of colopexy, deferentopexy and pediculated autograft of tunica vaginalis for occlusion of the hernial ring via abdominal access in a dog (Costa et al., 2017).

Two neoplasms of the anal gland (one malignant and one benign), two cutaneous (unidentified) tumors, and one cutaneous lipoma were surgically removed. Studies in Brazil found that neoplasia were the second (Bentubo et al., 2007; Fighera et al., 2008) or third (Trapp et al., 2010) most frequent cause of death in dogs.

There were two cases of rectal prolapse corrected by surgical replacement $(2 / 201,0.99 \%)$. The treatment for this is replacement, which may or may not be associated with colopexy (Guedes et al., 2012). In the cases described here, only replacement was performed. Patients were referred to the medical clinic for treatment of the cause of prolapse, probably verminosis, which is one of the most common causes of this disease (Aronson, 2007; Guedes et al., 2012).

Two cases of eventration were surgically corrected $(2 / 201,0.99 \%)$. This affection is usually due to trauma, and the correction is surgical (Soares et al., 2012).

Two cases of intramedullary pin removal were recorded (2/201, 0.99\%). Such procedures are considered minor, and are performed after the end of the surgical treatment of fractures by emplacing an internal prosthesis (i.e. intramedullary pin).

The following cases were represented by only one patient out of a total of nine patients (9/201, 4.48\%) not fitting the categories discussed thus far: limb amputation, incisional biopsy, evisceration correction, acetabular denervation, thoracic esophagotomy for removal of foreign body, umbilical herniorrhaphy, exploratory laparotomy, sialoadenectomy, and urethrostomy.

Among the surgical procedures performed during the study period, ovariohysterectomy was the most frequent, both for elective and therapeutic cases, emphasizing the importance of surgical sterilization, both to avoid unwanted pregnancy or reproductive diseases and to treat diseases of the reproductive system.

The high percentage of therapeutic surgical procedures that were performed reinforces the complexity of the cases attended to daily in a university teaching hospital.

\section{Conflict of interest}

All authors declare there were no conflicts of interest.

\section{Ethics Statement}

Approval of the Committee of Ethics on Experimentation with Animals (CEEA / UFPI: Protocol no. 063/11) was obtained for the above study. 


\section{References}

Aronson L. Reto e ânus. In: Slatter D, editor. Manual de cirurgia de pequenos animais. 3 a ed. vol. 1. São Paulo: Manole; 2007. p. 682-707.

Barbosa ALT, Schossler JEW. Luxação coxofemoral traumática em cães e gatos: estudo retrospectivo (1997-2006). Cienc Rural. 2009;39(6):1823-9. http://dx.doi.org/10.1590/S010384782009000600028 .

Bentubo H, Cardoso TG, Rocha LF, Bondan EF, Lallo MA. Estudo da longevidade de diferentes raças de cães na cidade de São Paulo. Braz J Vet Res Anim Sci. 2003;40:191-2.

Bentubo HDL, Tomaz MA, Bondan EF, Lallo MA. Expectativa de vida e causas de morte em cães na área metropolitana de São Paulo (Brasil). Cienc Rural. 2007;37(4):1021-6. http:// dx.doi.org/10.1590/S0103-84782007000400016.

Bezerra CH, Lopes RS, Franco A, Silva LLC, Caramico M, Tussini P, Toyofuku L, Dattelkremer TP. Levantamento de casos de janeiro a junho de 2012 atendidos na FisioCare Pet. Revista MV\&Z. 2013;11(2):71.

Biondi LR, Gentile LB, Rego AAMS, Noronha NP, Dagli MLZ. Canine mammary tumors in Santos, Brazil: clinicopathological and survival profile. Braz J Vet Res Anim Sci. 2014;51(3):252-62. http://dx.doi.org/10.11606/ issn.1678-4456.v51i3p252-262.

Costa JM No, Cardoso LG, Shorte RR, Santos GWM, Borges KB, Faria B, Quessada AM, Ribeiro CHA Fo. Associação de pexias intra-abdominais e autoenxerto pediculado de túnica vaginal para tratamento da hérnia perineal em cão - relato de caso. JIBI. 2017;2(2):38-45. https://doi. org/10.26694/jibi.v2i2.6157.

Cruz-Pinto CE, Stopiglia AJ, Matera JM, Arnoni FI. Análise da casuística das afecções cirúrgicas observadas na Clínica Cirúrgica de Pequenos Animais da FMVZ-USP no período de 1988 a 2007. Braz J Vet Res Anim Sci. 2015;52(1):41-7. http://dx.doi.org/10.11606/issn.1678-4456.v52i1p41-47.

Evangelista LSM, Quessada AM, Alves RPA, Lopes RRFB, Gonçalves LMF. Função renal em cadelas com piometra antes e após ovariosalpingohisterectomia. Acta Vet Brasilica. 2010;4(3):153-61.

Fighera RA, Silva MC, Souza TM, Brum JS, Kommers GD, Graça DL, Irigoyen LF, Barros CSL. Aspectos patológicos de 155 casos fatais de cães atropelados por veículos automotivos. Cienc Rural. 2008;38(5):1375-80. http://dx.doi.org/10.1590/ S0103-84782008000500028.
Franco LF, Silva-Molano RF. Frecuencia de presentación de la casuística atendida en el área de clínica quirúrgica del Hospital Veterinario de la Universidad de Caldas (20022004). Vet Zootec. 2009;3(2):51-5.

Guedes RL, Linhares MT, Castro IF Jr, Simeoni CP, Cunha TO, Gomes C, Brun MV, Pippi NL. Colopexia videoassistida com dois portais para o tratamento de prolapso retal recidivante. Cienc Rural. 2012;42(1):112-5. http://dx.doi. org/10.1590/S0103-84782012000100018.

Inoe AP, Zafaneli MCG, Cunha CG, Leme MC, Neiverth KP, Zafanelli CCG. Estudo retrospectivo de 228 ovariosalpingohisterectomias realizadas no Hospital veterinário da UNIPAR no período de janeiro de 1999 a julho de 2004. Arq Ciênc Vet Zool UNIPAR. 2004;7(2):28.

Kemper B, Diamante GAC. Estudo retrospectivo das fraturas do esqueleto apendicular de cães atendidos no Hospital Veterinário da Universidade Norte do Paraná (Unopar) no período de Janeiro de 2007 a Março de 2009. J Health Sci. 2010;12(2):23-6.

Lopes MAI. Abordagem e maneio médico-cirúrgico de feridas abertas em cães e gatos: caracterização etiológica e estudo de padrões traumáticos [dissertação]. Lisboa: Faculdade de Medicina Veterinária, Universidade de Lisboa; 2016.

Magalhães CS, Lima WC, Lima DASD, Quessada AM, Dornelles DEM, Costa JM No. Conhecimento de tutores de cães sobre tumor de mama em cadelas. Acta Vet Brasilica. 2016;10(2):186-9. http://dx.doi.org/10.21708/ avb.2016.10.2.5537.

Marques DRC, Russo C, Inañez JF. Utilização de pericárdio bovino conservado em glicerina $98 \%$ na herniorrafia perineal em cães - relato de 12 casos. Arq Ciênc Vet Zool UNIPAR. 2015;18(3):185-90. https://doi.org/10.25110/ arqvet.v18i3.2015.5540.

Mortari AC, Rahal SC. Hérnia perineal em cães. Cienc Rural. 2005;5(5):1220-8. http://dx.doi.org/10.1590/S010384782005000500040 .

Mostachio GQ, Apparício M, Motheo TF, Alves AE, Vicente WR. Administração de toxina botulínica A e a orquiectomia no tratamento da hiperplasia prostática benigna do cão. Cienc Rural. 2015;45(9):1654-9. http:// dx.doi.org/10.1590/0103-8478cr20141253. 
Niza RGR. Clínica e cirurgia em animais de companhia [dissertação]. Évora: Escola de Ciências e Tecnologia, Universidade de Évora; 2015.

Ribeiro ACS. Maneio do cão geriátrico nas 48 horas póscirúrgicas [dissertação]. Lisboa: Faculdade de Medicina Veterinária, Universidade de Lisboa; 2016.

Ribeiro JC. Hérnia perineal em cães: avaliação e resolução cirúrgica - artigo de revisão. Rev Lusófona Cienc Med Vet. 2010;3:26-35.

Rodrigues NM, Quessada AM, Silva FL, Silva EMC, Costa Neto JM, Lima WC. Epidemiologia e risco anestésico de cães portadores de otohematoma. Acta Sci Vet. 2016;44:1-6. https://doi.org/10.22456/1679-9216.80930

Shmon C. Avaliação e preparação do paciente e da equipe cirúrgica. In: Slatter D. Manual de cirurgia de pequenos animais. 3a. ed. vol. 1. São Paulo: Manole; 2007. p. 162-70.

Silva EF Fo, Prado TD, Ribeiro RG, Fortes RM. Urolitíase canina. Enciclopédia Biosfera. 2013;9(17):2517-36.

Silveira CPB, Machado EAA, Silva WM, Marinho TCMS, Ferreira ARA, Bürger CP, Costa JMD No. Estudo retrospectivo de ovariossalpingo-histerectomia em cadelas e gatas atendidas em Hospital Veterinário Escola no período de um ano. Arq Bras Med Vet Zootec. 2013;65(2):335-40. http://dx.doi. org/10.1590/S0102-09352013000200005.

Soares MB, Stangherlin GF, Cristofari MS, Rosa NS, Ramos T, Brun MV. Hérnia abdominal traumática por mordedura em canino macho: relato de caso. Acta Sci Vet. 2012;40:56.

Souza MMD, Rahal SC, Otoni CC, Mortari AC, Lorena SERS. Luxação de patela em cães: estudo retrospectivo.
Arq Bras Med Vet Zootec. 2009;61(2):523-6. http://dx.doi. org/10.1590/S0102-09352009000200035.

Souza MMD, Rahal SC, Padovani CR, Mamprim MJ, Cavini $\mathrm{JH}$. Afecções ortopédicas dos membros pélvicos em cães: estudo retrospectivo. Cienc Rural. 2011;41(5):852-7. http:// dx.doi.org/10.1590/S0103-84782011005000055.

Trapp SM, Iacuzio AI, Barca FA Jr, Kemper B, Silva LC, Okano W, Tanaka NM, Grecco FCAR, Cunha LFC Fo, Sterza FDAM. Causas de óbito e razões para eutanásia em uma população hospitalar de cães e gatos. Braz J Vet Res Anim Sci. 2010;47(5):395-402. http://dx.doi.org/10.11606/ issn.1678-4456.bjvras.2010.26821.

Vidane AS, Elias MZJ, Cardoso JMM, Come JASS, Harun $\mathrm{M}$, Ambrósio CE. Incidência de fraturas em cães e gatos da cidade de Maputo (Moçambique) no período de 19982008. Cienc Anim Bras. 2014;15(4):490-4. http://dx.doi. org/10.1590/1089-6891v15i424279.

Xavier DG. Casuística clínica e cirúrgica de uma clínica veterinária na cidade de Camaquã/RS, durante o período de 2008 a 2011 [monografia]. Mossoró: Departamento de Ciências Animais, Universidade Federal Rural do SemiÁrido; 2012.

Financial support: Financial support was provided by CNPq - Conselho Nacional de Desenvolvimento Científico e Tecnológico.

Authors Contributions: All authors participated in the writing of the article, considering the reading and review stages. 